\title{
Article \\ Semi-Transparent Organic Photovoltaic Cells with Dielectric/Metal/Dielectric Top Electrode: Influence of the Metal on Their Performances
}

\author{
Linda Cattin ${ }^{1, *}$, Guy Louarn ${ }^{1}\left(\mathbb{C}\right.$, Mustapha Morsli $^{2}$ and Jean Christian Bernède ${ }^{3, *}$ (C) \\ 1 Institut des Matériaux Jean Rouxel (IMN), Université de Nantes, CNRS, UMR 6502, 2 rue de la Houssinière, \\ BP 92208, F-44322 Nantes, France; guy.louarn@cnrs-imn.fr \\ 2 Faculté des Sciences et des Techniques, Université de Nantes, 2 rue de la Houssinière, BP 92208, \\ F-44000 Nantes, France; Saber.Morsli@univ-nantes.fr \\ 3 MOLTECH-Anjou, CNRS, UMR 6200, Université de Nantes, 2 rue de la Houssinière, BP 92208, \\ F-44322 Nantes, France \\ * Correspondence: Linda.Cattin-Guenadez@univ-nantes.fr (L.C.); \\ jean-christian.bernede@univ-nantes.fr (J.C.B.); Tel.: +33-51-12-55-31 (L.C.)
}

Citation: Cattin, L.; Louarn, G.;

Morsli, M.; Bernède, J.C.

Semi-Transparent Organic

Photovoltaic Cells with

Dielectric/Metal/Dielectric Top

Electrode: Influence of the Metal on

Their Performances. Nanomaterials

2021, 11, 393. https://doi.org/

10.3390/nano11020393

Received: 26 December 2020

Accepted: 27 January 2021

Published: 4 February 2021

Publisher's Note: MDPI stays neutral with regard to jurisdictional claims in published maps and institutional affiliations.

Copyright: (c) 2021 by the authors. Licensee MDPI, Basel, Switzerland. This article is an open access article distributed under the terms and conditions of the Creative Commons Attribution (CC BY) license (https:/ / creativecommons.org/licenses/by/ $4.0 /)$.

\begin{abstract}
In order to grow semi-transparent organic photovoltaic cells (OPVs), multilayer dielectric/metal/dielectric (D/M/D) structures are used as a transparent top electrode in inverted OPVs. Two different electrodes are probed, $\mathrm{MoO}_{3} / \mathrm{Ag} / \mathrm{MoO}_{3}$ and $\mathrm{MoO}_{3} / \mathrm{Ag} / \mathrm{Cu}: \mathrm{Ag} / \mathrm{ZnS}$. Both of them exhibit high transmission in visible and small sheet resistance. Semi-transparent inverted OPVs using these electrodes as the top anode are probed. The active organic layers consist in the SubPc/ $\mathrm{C}_{60}$ couple. The dependence of the OPV performances on the top electrode was investigated. The results show that far better results are achieved when the top anode $\mathrm{MoO}_{3} / \mathrm{Ag} / \mathrm{MoO}_{3}$ is used. The OPV efficiency obtained was only $20 \%$ smaller in comparison with the opaque OPV, but with a transparency of nearly $50 \%$ in a broad range of the visible light $(400-600 \mathrm{~nm})$. In the case of $\mathrm{MoO}_{3} / \mathrm{Ag} / \mathrm{Cu}: \mathrm{Ag} / \mathrm{ZnS}$ top anode, the small efficiency obtained is due to the presence of some $\mathrm{Cu}$ diffusion in the $\mathrm{MoO}_{3}$ layer, which degrades the contact anode/organic material.
\end{abstract}

Keywords: semi-transparent organic photovoltaic cells; dielectric/metal/dielectric transparent electrode; top transparent anode; $\mathrm{MoO}_{3} / \mathrm{Ag} / \mathrm{MoO}_{3}$; inverted planar heterojunction; SubPc/C60 active layers

\section{Introduction}

The growing interest in organic photovoltaic cells (OPVs) is due to the fact that they possess some specific advantages such as light weight, intrinsic flexibility, and possible semi-transparency of organic thin films [1]. More specifically, semi-transparent OPVs attract strong interest due to the efforts currently directed toward building integrated photovoltaics (BIPVs). Recently, much research has focused on improving OPV efficiency [1-4], but some applications, such as BIPV, induce the use of semi-transparent OPVs, which are less efficient than the usual opaque OPVs because they have to transmit a significant amount of visible light [5,6]. Therefore, for semi-transparent OPVs, it is not appropriate to use optimal organic layer thickness. It is known that, the diffusion length of excitons being smaller than the organic layer thickness necessary to absorb light, the geometry of bulk heterojunction (BHJ) was used with success [7-11], while in the case of planar heterojunctions (PHJs), the excitons created too far from the electron donor/electron acceptor interface are lost, which, contrary to the case of BHJs, limits the thickness of PHJs and, therefore, their efficiency [12]. However, as said above, in the case of semi-transparent OPVs, we must not use the optimum thickness to preserve some OPV transparency, so we chose the PHJ-OPV configuration to grow semi-transparent devices. Such configuration allows for using small molecules and deposition under vacuum. Small molecules have a number 
of benefits such as easy preparation and purification and a unique final molecule that prevents the problem of batch-to-batch reproducibility [13-15]. Furthermore, the thermal deposition technique allows for easy fabrication of multilayer devices with precise control of the thickness of each layer [16,17]. Usually, the electrodes of opaque OPVs consist of a transparent conductive electrode (TCE), often an ITO (Indium Tin Oxide) thin film deposited onto a glass substrate, and a metal electrode, often aluminum. The high reflectivity of $\mathrm{Al}$ allows light to be reinserted into the organic layers. To achieve semi-transparent OPVs with acceptable performances, the main challenge is the substitution of a transparent electrode with high conductivity with a metal electrode [18]. Different solutions are possible, among them, dielectric/metal/dielectric (DMD) structures $[19,20]$. They possess quite equilibrated optical and electrical properties; moreover, they are easy to realize given the technique we have chosen to use via successive thermal sublimation/evaporation. In DMD, $\mathrm{M}$ allows obtaining small sheet resistance, but its high reflectivity strongly penalizes the light transmission. Thus, to obtain the transmission of the visible light, it is necessary to sandwich the $\mathrm{M}$ layer between two high refractive index dielectrics. $\mathrm{MoO}_{3}$ is one of the possible dielectrics; it is well known that it is very efficient as a hole-transporting layer (HTL) at the anode/electron donor interface [21,22]. Therefore, in the present work, $\mathrm{MoO}_{3}$ was chosen as the dielectric. As for the metal, Ag is commonly selected because it exhibits the highest metal conductivity coupled with the lowest absorption in the visible range among the metals [23]. Nevertheless, Ag is quite expensive, and it would be of high interest to use a cheaper metal. Therefore, we also used $\mathrm{Cu}$, whose optical and electrical properties are very close to those of $\mathrm{Ag}$. Unfortunately, $\mathrm{Cu}$ tends to diffuse into transition metal oxides such as $\mathrm{MoO}_{3}$ [24], so we tried to improve DCuD stability through the use of $\mathrm{ZnS}$ dielectric and $\mathrm{Cu}: \mathrm{Ag}$ alloy [25]. After optimization, these DMD electrodes are used as top electrodes in inverted OPVs, such as ITO $/ \mathrm{Alq}_{3} / \mathrm{C}_{60} / \mathrm{SubPc} / \mathrm{DMD}$. We chose the inverted OPV configuration due to its better stability [26]. The study shows that, even after the DMD structure optimization, the best results are obtained with DagD top electrodes. In comparison with the reference $\mathrm{OPV}$, i.e., with $\mathrm{Al}$ as the top electrode, the efficiencies of the semi-transparent OPVs are only $20 \%$ smaller, but with a transparency of nearly $50 \%$ in a broad range of the visible light $(400-600 \mathrm{~nm})$.

\section{Materials and Methods}

The deposition and characterization techniques have already been described, and they are recalled in Supporting Information S1 and S2.

The inverted OPVs were deposited under vacuum (see Supporting Information S1), and they were as follows: ITO $/ \mathrm{Alq}_{3} / \mathrm{C}_{60} / \mathrm{SubPc} / \mathrm{DMD}$ (Figure 1). They are based on the electron acceptor/electron donor couple (EA/ED): $\mathrm{C}_{60} / \mathrm{SubPc}$. SubPc is known for its high absorption coefficient and $\mathrm{C}_{60}$ for its high efficiency as an electron acceptor [27]. The thickness of these layers in inverted OPVs was earlier optimized: $40 \mathrm{~nm}$ for $\mathrm{C}_{60}$ and $16 \mathrm{~nm}$ for SubPc [28]. The buffer layer inserted between the cathode and the electron acceptor, which is called the exciton blocking layer (EBL) in the case of PHJ-OPVs [29], is a thin layer $(9 \mathrm{~nm})$ of $\mathrm{Alq}_{3}$. Often, the EBL consists in a bathocuproine layer [26]; however, it was shown that $\mathrm{Alq}_{3}$ allows obtaining more stable OPVs, which justifies our choice [30]. Regarding the DMD top electrode, the first dielectric layer also serves as a hole-transporting layer (HTL), so, as evocated above, it consists in a $\mathrm{MoO}_{3}$ layer. For the other layers of the $\mathrm{MoO}_{3} / \mathrm{M} / \mathrm{D}$ structure, we used two metals: either Ag or Cu:Ag alloy and $\mathrm{ZnS}$ as the dielectric. The atomic concentration of $\mathrm{Ag}$ in the alloy was 5 at\%. In the case of the reference opaque electrode, the top electrode was $\mathrm{MoO}_{3} / \mathrm{Al}$. We have already optimized the DMD structures, either as transparent conductive structures or as bottom electrodes in opaque OPVs $[23,25]$. Here, due to the fact that the DMD structures were deposited onto stacked ITO/Alq $3 / \mathrm{C}_{60} /$ SubPc layers, we had to check the optimum thickness of the $\mathrm{MoO}_{3}$ interfacial layer. 


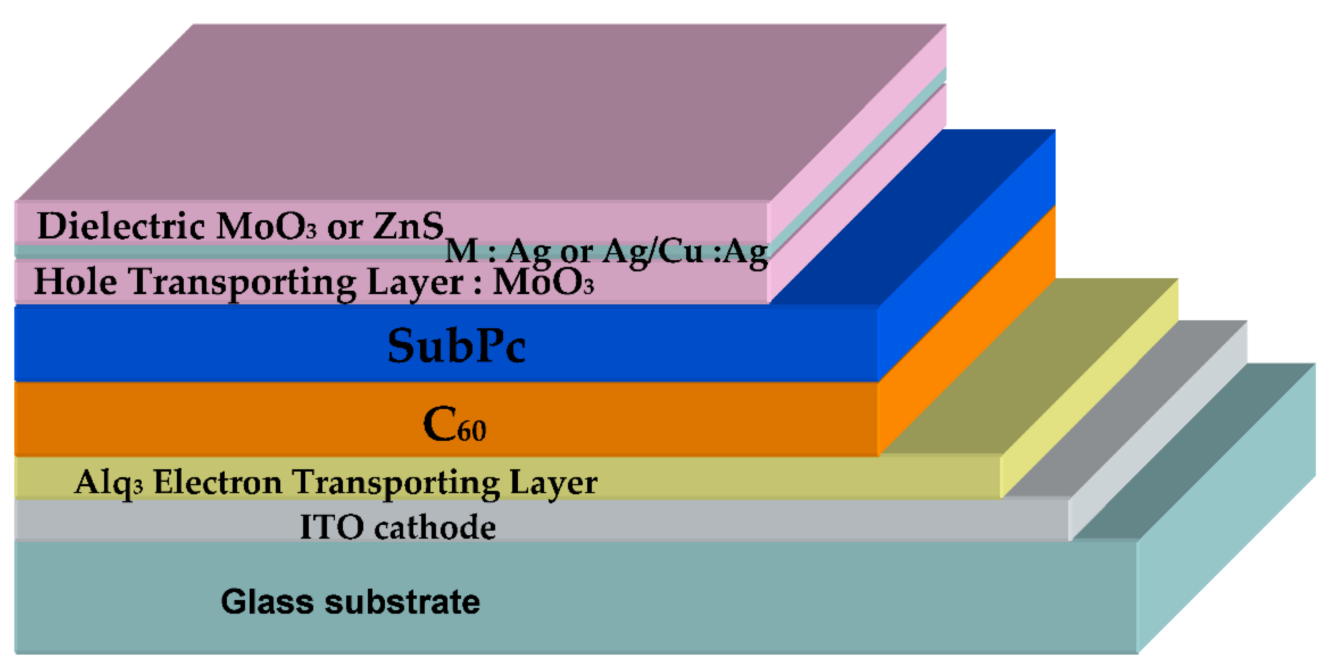

Figure 1. Typical inverted semi-transparent organic photovoltaic cell (OPV).

The different devices were characterized using the following techniques: optical transmission and absorption measurements, electrical conductivity measurements, X-ray photoelectron spectroscopy, J-V characteristics of OPV in the dark, and under AM1.5 solar spectrum.

These different techniques are described in Supporting Information S2.

\section{Results and Discussion}

Regarding the DMD structures, when $\mathrm{Ag}$ was used as metal and $\mathrm{MoO}_{3}$ as dielectric, reproducible results were obtained. The performances of the structures Glass $/ \mathrm{MoO}_{3}$ $(20 \mathrm{~nm}) / \mathrm{Ag}(10 \mathrm{~nm}) / \mathrm{MoO}_{3}(35 \mathrm{~nm})$ are summarized in Table 1, and the visible optical transmission is shown in Figure 2.

Table 1. Main parameters of the transparent electrodes.

\begin{tabular}{cccc}
\hline Transparent Electrode & $\begin{array}{c}\text { Sheet Resistance } \\
(\boldsymbol{\Omega} / \mathbf{s q})\end{array}$ & $\begin{array}{c}\text { Maximum Transmission } \\
(\mathbf{\%})\end{array}$ & ${\text { Figure of } \mathbf{M e r i t}^{\mathbf{1 0}} \mathbf{(}(\boldsymbol{\Omega})^{-\mathbf{1}}}$ \\
\hline $\mathrm{ITO}$ & 15 & 93.5 & 34 \\
$\mathrm{MoO}_{3} / \mathrm{Ag} / \mathrm{MoO}_{3}$ & 5 & 90.1 & 70 \\
$\mathrm{MoO}_{3} / \mathrm{Ag}(1 \mathrm{~nm}) / \mathrm{Cu}: \mathrm{Ag}(16 \mathrm{~nm}) / \mathrm{ZnS}$ & 33 & 85.2 & 6.1 \\
$\mathrm{MoO}_{3} / \mathrm{Ag}(2 \mathrm{~nm}) / \mathrm{Cu}: \mathrm{Ag}(15 \mathrm{~nm}) / \mathrm{ZnS}$ & 29 & 83.9 & 6.0 \\
\hline
\end{tabular}

From optical and electrical measurements, we have calculated $\Phi_{\mathrm{M}}$, the figure of merit proposed by Haack using the empiric formulae [31]:

$$
\Phi_{\mathrm{M}}=\mathrm{T}^{10} / \sigma_{\mathrm{sh}}
$$

where $\Phi_{M}$ is the figure of merit, T is the transmission of light, and $\sigma_{\text {sh }}$ is the sheet resistance.

It allows for comparing the "opto-electrical" performances of the different electrodes.

In the case of $\mathrm{MoO}_{3} / \mathrm{Ag} / \mathrm{MoO}_{3}$ structures, the optimum thickness of the layers has been determined in previous publications to be $20 \mathrm{~nm} / 10 \mathrm{~nm} / 35 \mathrm{~nm}$, respectively [23]. The thickness of the Ag layer, $10 \mathrm{~nm}$, corresponds to the percolation threshold of the metal layer; for less thickness, the metal film is discontinuous; for thicker films, the reflectivity and absorption of the metal film increase. 


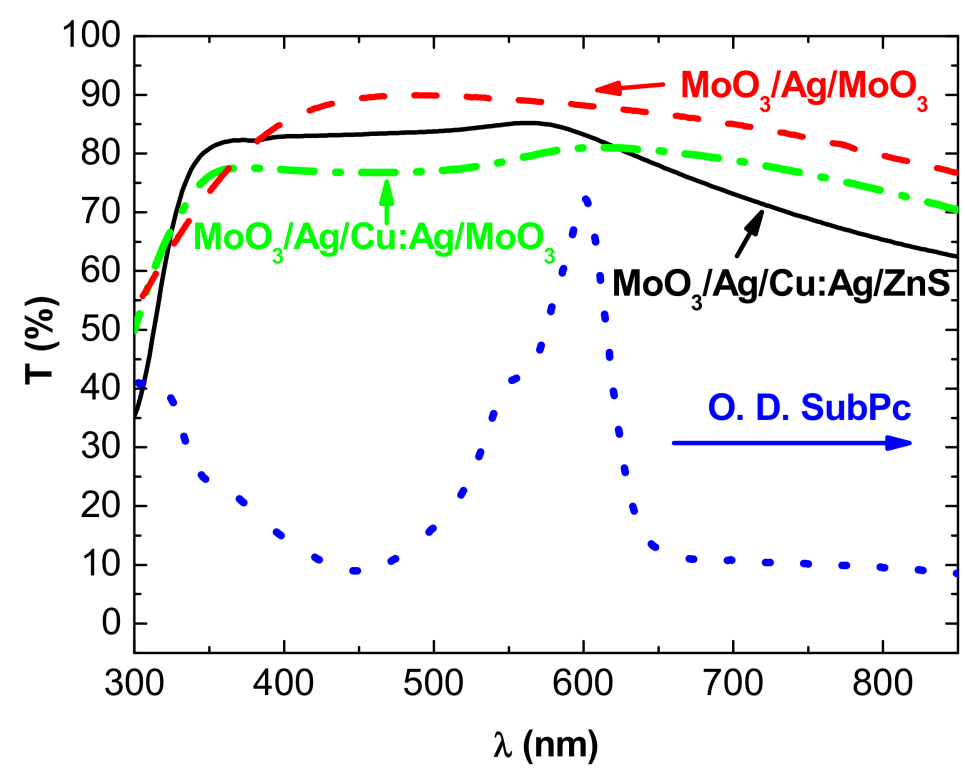

Figure 2. Transmission spectra of (-) glass $/ \mathrm{MoO}_{3}(20 \mathrm{~nm}) / \mathrm{Ag}(10 \mathrm{~nm}) / \mathrm{MoO}_{3}(35 \mathrm{~nm})$, (一) $\mathrm{MoO}_{3}(20 \mathrm{~nm}) / \mathrm{Ag}(2 \mathrm{~nm}) / \mathrm{Cu}: \mathrm{Ag}(15 \mathrm{~nm}) / \mathrm{ZnS}(45 \mathrm{~nm})$ structures, and $(-\bullet-\bullet \bullet) \mathrm{MoO}_{3}(20 \mathrm{~nm}) / \mathrm{Ag}$ $(2 \mathrm{~nm}) / \mathrm{Cu}: \mathrm{Ag}(15 \mathrm{~nm}) / \mathrm{MoO}_{3}(45 \mathrm{~nm})$ structures, and $(\bullet \bullet \bullet)$ absorption spectrum of SubPc.

In the case of copper, it is not so easy to grow performing TCE. In fact, we have already shown that $\mathrm{Cu}$ diffuses easily and spontaneously into $\mathrm{MoO}_{3}$ [24]; therefore, in the structures $\mathrm{MoO}_{3} / \mathrm{Cu} / \mathrm{MoO}_{3}$, we inserted $\mathrm{ZnS}$ in the $\mathrm{MoO}_{3}$ top layer in such a way that we used $\mathrm{MoO}_{3} / \mathrm{Cu} / \mathrm{ZnS}$ structures, the diffusion of $\mathrm{Cu}$ in $\mathrm{ZnS}$ being far smaller than in $\mathrm{MoO}_{3}$. However, we cannot substitute $\mathrm{ZnS}$ for the other $\mathrm{MoO}_{3}$ layer because, while $\mathrm{MoO}_{3}$ is an excellent hole-extracting layer, $\mathrm{ZnS}$ is not, and the performances of the OPVs using $\mathrm{ZnS} / \mathrm{M} / \mathrm{ZnS}$ top electrodes were very poor. Thus, it is necessary to keep $\mathrm{MoO}_{3}$ as an interface layer between the SubPc layer and the metal layer. Nevertheless, since we know that $\mathrm{Cu}$ diffuses spontaneously into $\mathrm{MoO}_{3}$ [24], we introduced an ultra-thin $\mathrm{Ag}$ layer at the interface $\mathrm{MoO}_{3} / \mathrm{Cu}$. We have already shown that such an ultra-thin Ag layer significantly improves the stability of $\mathrm{MoO}_{3} / \mathrm{Cu}$ structures [23]. Nevertheless, it is not sufficient to obtain really stable electrodes. Therefore, we used a $\mathrm{Cu}$ :Ag alloy. We have shown that the structures using such an alloy with 5 at.\% of Ag exhibit acceptable stability [25]. Using dielectric layer thicknesses determined previously, typical results are shown in Table 1 and Figure 2. When the metal is $\mathrm{Cu}$, regardless of the dielectric used, the general shape of the transmission curve is similar but, due to higher $\mathrm{Cu}$ diffusion in $\mathrm{MoO}_{3}$, the curve is flatter when the two dielectric layers are $\mathrm{MoO}_{3}$. It must be noted that in the case of copper, it is necessary to use a thicker metal film to obtain $\mathrm{MoO}_{3} / \mathrm{M} / \mathrm{ZnS}$ structure with acceptable sheet resistance, which has a thickness of $17 \mathrm{~nm}$. The figure of merit of the structures using $\mathrm{Cu}: \mathrm{Ag}$ metal layer is slightly better with $2 \mathrm{~nm}$ of $\mathrm{Ag}$ than a structure with $1 \mathrm{~nm}$ of $\mathrm{Ag}$. Moreover, $2 \mathrm{~nm}$ of Ag permits obtaining structures more stable than those with $1 \mathrm{~nm}$ of Ag. As already mentioned regarding the properties of DMD structures, there is a critical thickness of the M layer, which corresponds to the percolation threshold of the metal layer; for less thickness, the metal film is discontinuous and the structure is insulating; for thicker films, the sheet resistance decreases slowly but the light transmission decreases. In fact, the layer thickness corresponding to the percolation threshold of the electrical properties is also of the optimum thickness for optical properties. Below this thickness, the metal film is discontinuous, which results in enhanced absorbance due to plasmonic resonances, involving a decreased transmittance. For thicknesses beyond the threshold value, the reflectivity and absorbance of the metal layer increase, inducing a decreased transmission of light $[21,23,32]$.

In Figure 2, we introduce the absorption curve of SubPc. It can be seen that the maximum of absorption of SubPc corresponds to the transmission maximum of the DMD 
structures, which can be favorable for a compromise between the absorption and transmission of semi-transparent OPVs. On the other hand, it can be seen that, on the ultraviolet side of the spectrum, the transmission is limited due to the optical band gap of the dielectrics, while in the near-infrared domain, the transmission decreases due to the plasma effect resulting from the high concentration of mobile electrons in the IR region, which allows having conductive electrodes.

Therefore, at the beginning of the study of the semi-transparent OPVs, we used $\mathrm{MoO}_{3}$ $(20 \mathrm{~nm}) / \mathrm{Ag}(10 \mathrm{~nm}) / \mathrm{MoO}_{3}(35 \mathrm{~nm})$ and $\mathrm{MoO}_{3}(20 \mathrm{~nm}) / \mathrm{Ag}(2 \mathrm{~nm}) / \mathrm{Cu}: \mathrm{Ag}(15 \mathrm{~nm}) / \mathrm{ZnS}$ $(45 \mathrm{~nm})$ top electrodes. Unfortunately, the efficiency of the OPVs was quite low, with high-series resistances. $\mathrm{MoO}_{3}$ being resistive-a disappointing result-was attributed to the thickness of the interfacial $\mathrm{MoO}_{3}$ layer, $20 \mathrm{~nm}$. Therefore, it was necessary to decrease this thickness. The experimental study shows that a thickness of $10 \mathrm{~nm}$ allows obtaining optimum results.

Figure 3 displays the spectral transmission of the complete OPVs: ITO/ $\mathrm{Alq}_{3} / \mathrm{C}_{60} /$ SubPc/DMD, the DMD top electrode being either $\mathrm{MoO}_{3}(10 \mathrm{~nm}) / \mathrm{Ag}(10 \mathrm{~nm}) / \mathrm{MoO}_{3}$ (35 nm) or $\mathrm{MoO}_{3}(10 \mathrm{~nm}) / \mathrm{Ag}(2 \mathrm{~nm}) / \mathrm{Cu}: \mathrm{Ag}(15 \mathrm{~nm}) / \mathrm{ZnS}(45 \mathrm{~nm})$.

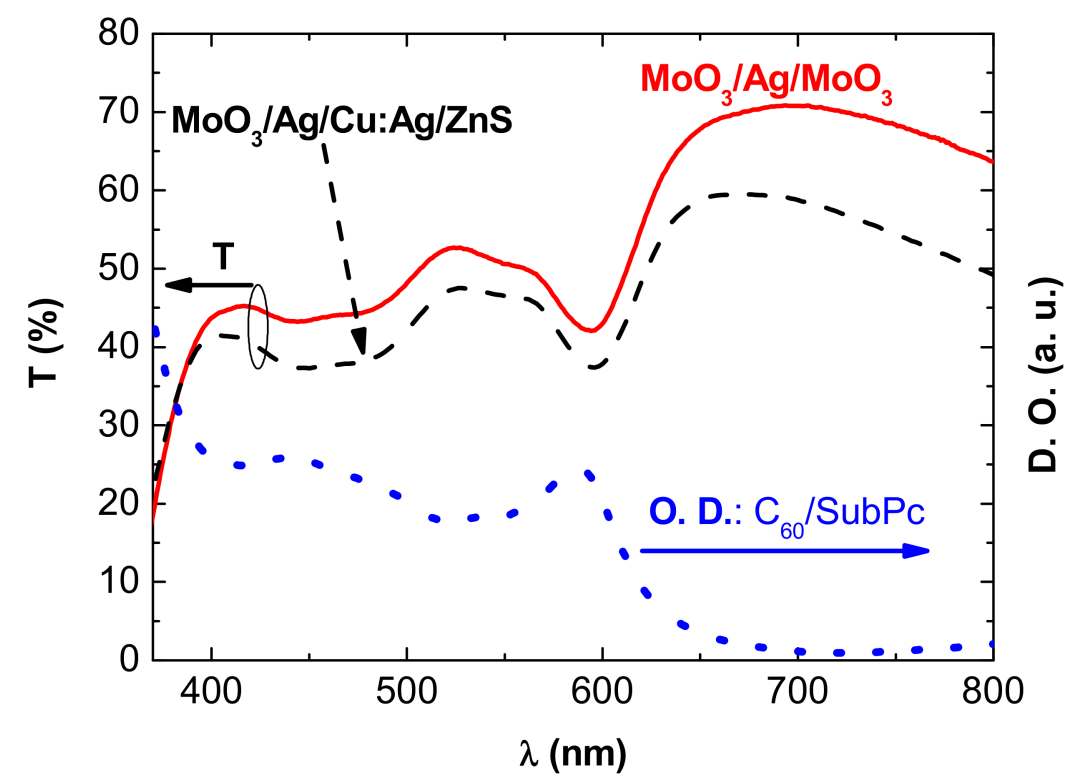

Figure 3. Transmission spectra of OPVs with different top electrodes: (-) $\mathrm{MoO}_{3}(10 \mathrm{~nm}) / \mathrm{Ag}$ $(10 \mathrm{~nm}) / \mathrm{MoO}_{3}(35 \mathrm{~nm})$ and (-----) $\mathrm{MoO}_{3}(10 \mathrm{~nm}) / \mathrm{Ag}(2 \mathrm{~nm}) / \mathrm{Cu}: \mathrm{Ag}(15 \mathrm{~nm}) / \mathrm{ZnS}(45 \mathrm{~nm})$ and (•...) absorption spectrum of the OPV without top electrode: Glass $/ \mathrm{ITO} / \mathrm{Alq}_{3} / \mathrm{C}_{60} / \mathrm{SubPc}$.

Obviously, the transmission spectrum of the opaque OPV, with a $100 \mathrm{~nm}$ thick $\mathrm{Al}$ top electrode, is null. In the case of semi-transparent OPVs, i.e., when the top electrode is either $\mathrm{MoO}_{3}(10 \mathrm{~nm}) / \mathrm{Ag}(10 \mathrm{~nm}) / \mathrm{MoO}_{3}(35 \mathrm{~nm})$ or $\mathrm{MoO}_{3}(10 \mathrm{~nm}) / \mathrm{Ag}(2 \mathrm{~nm}) / \mathrm{Cu}: \mathrm{Ag}$ $(15 \mathrm{~nm}) / \mathrm{ZnS}(45 \mathrm{~nm})$, the transmission is higher for wavelengths exceeding $\lambda=615 \mathrm{~nm}$, due to the absorption spectrum shape of SubPc (Figure 3). After reaching a maximum value, the transmission gradually decreases, following the decreasing transmission curve of the DMD structures. On the whole spectrum, the transmission difference between the two types of OPVs follows the difference in transmission of the DMDs themselves. On the other hand, as expected, their minimum transmission, situated between $550 \mathrm{~nm}$ and $615 \mathrm{~nm}$, corresponds to the domain of maximum absorption of SubPc. More globally, the transmission curve of the OPVs is the inverted image of the absorption curve, which confirms the relatively good transmission of light by the anodes used.

The J-V characteristics of the inverted OPVs are shown in Figures 4 and 5 and summarized in Table 2. 


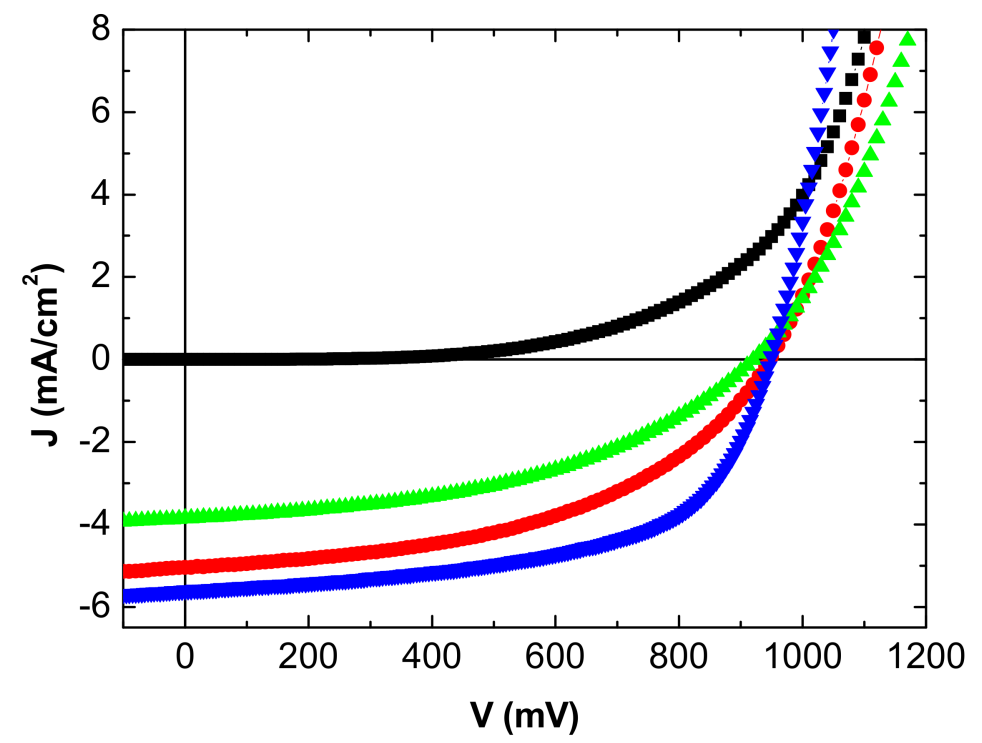

Figure 4. J-V characteristics inverted OPV with $\mathrm{MoO}_{3} / \mathrm{Ag} / \mathrm{MoO}_{3}$ as top anode: in the dark (ם), under light from the ITO side $(\bullet)$, and from the $\mathrm{MoO}_{3} / \mathrm{Ag} / \mathrm{MoO}_{3}$ side $(\triangle)$. Classical $\mathrm{MoO}_{3} / \mathrm{Al}$ top anode $(\boldsymbol{\nabla})$.

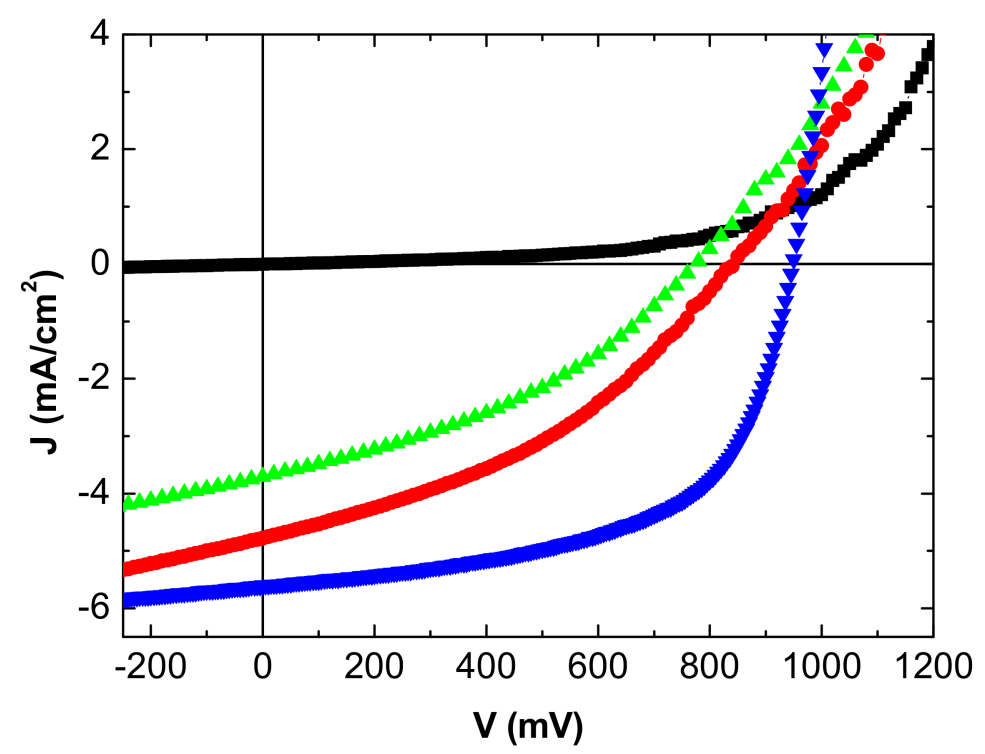

Figure 5. J-V characteristics inverted OPV with $\mathrm{MoO}_{3} / \mathrm{Ag} / \mathrm{Cu}: \mathrm{Ag} / \mathrm{ZnS}$ as top anode: in the dark (ם), under light from the ITO side $(\bullet)$ and from the $\mathrm{MoO}_{3} / \mathrm{Ag} / \mathrm{Cu}: \mathrm{Ag} / \mathrm{ZnS}$ side $(\triangle)$. Classical $\mathrm{MoO}_{3} / \mathrm{Al}$ top anode $(\boldsymbol{\nabla})$.

Table 2. Parameters of the inverted OPVs using different top anodes.

\begin{tabular}{|c|c|c|c|c|c|c|c|}
\hline Anode & Light Side & Voc & Jsc & FF & $\eta$ & Rs & Rsh \\
\hline $\mathrm{Al} / \mathrm{MoO}_{3}$ & ITO & 0.94 & 5.60 & 57 & 3.00 & 20 & 1800 \\
\hline $\mathrm{MoO}_{3} / \mathrm{Ag} / \mathrm{MoO}_{3}$ & ITO & 0.94 & 5.04 & 48 & 2.34 & 30 & 1200 \\
\hline $\mathrm{MoO}_{3} / \mathrm{Ag} / \mathrm{MoO}_{3}$ & DMD & 0.92 & 3.85 & 45 & 1.61 & 35 & 1000 \\
\hline $\mathrm{MoO}_{3} / \mathrm{Ag} / \mathrm{Cu}: \mathrm{Ag} / \mathrm{ZnS}$ & ITO & 0.84 & 4.77 & 40 & 1.55 & 40 & 700 \\
\hline $\mathrm{MoO}_{3} / \mathrm{Ag} / \mathrm{Cu}: \mathrm{Ag} / \mathrm{ZnS}$ & DMD & 0.43 & 3.71 & 39 & 1.10 & 40 & 500 \\
\hline
\end{tabular}


The reference OPV with the opaque Al top electrode gives the best results, which is not unexpected. Nevertheless, in the case of the $\mathrm{MoO}_{3} / \mathrm{Ag} / \mathrm{MoO}_{3}$ top anode, when the OPV is illuminated on the ITO side, the efficiency reached is not too far from that obtained with the Al top electrode.

While the open circuit voltage Voc is stable, the efficiency decrease is due to the short circuit-current-Jsc-and the Fill Factor (FF). The reflectivity of the Al top anode is far higher than that of $\mathrm{MoO}_{3} / \mathrm{Ag} / \mathrm{MoO}_{3}$, which justifies the decrease in Jsc.

Regarding FF, the Ag film thickness being only $10 \mathrm{~nm}$, its homogeneity must be less than that of the $100 \mathrm{~nm}$ thick Al layer, which should induce interface traps and a higher sheet resistance as shown by the increase in series resistance. When deposited onto organic layers, the sheet resistance of the $\mathrm{MoO}_{3} / \mathrm{Ag} / \mathrm{MoO}_{3}$ electrode is probably not as low as when deposited onto a polished glass substrate.

This effect is reinforced when the OPV is illuminated on the $\mathrm{MoO}_{3} / \mathrm{Ag} / \mathrm{MoO}_{3}$ side. To the effect of the low reflectivity of the electrode and higher sheet resistance, we must add the smaller light transmission; all these losses result in a deterioration of the OPV performances, mainly in a significant decrease in Jsc.

In the case of $\mathrm{MoO}_{3} / \mathrm{Ag} / \mathrm{Cu}: \mathrm{Ag} / \mathrm{ZnS}$ as the top anode, the performances obtained are far smaller than those of the reference OPV. In order to understand such poor results, we have proceeded to do some more characterization. We have already shown that the presence of $\mathrm{Cu}$ at the organic material/anode interface induces severe degradation of the OPVs, so we have studied the profile of the $\mathrm{MoO}_{3} / \mathrm{Ag} / \mathrm{Cu}: \mathrm{Ag} / \mathrm{ZnS}$ structure. In order to reproduce the experimental conditions of the OPVs, we deposited onto a glass substrate the layer sequence $\mathrm{MoO}_{3} / \mathrm{Ag} / \mathrm{Cu}: \mathrm{Ag} / \mathrm{ZnS}$. Generally, when thin layers are superimposed, the higher the number of layers superimposed, the rougher the sample surface is. This makes it more difficult to interpret an XPS profile because following this roughness, we lose resolution. Subsequently, we chose to make the profile on a sample deposited on glass.

The XPS profile obtained on such glass $/ \mathrm{MoO}_{3} / \mathrm{Ag} / \mathrm{Cu}: \mathrm{Ag} / \mathrm{ZnS}$ multilayer structure is reported in Figure 6. To check the influence of the thin Ag layer introduced between the $\mathrm{Cu}$ and $\mathrm{MoO}_{3}$ layers, we also present the profile of a glass $/ \mathrm{MoO}_{3} / \mathrm{Cu}: \mathrm{Ag} / \mathrm{ZnS}$ multilayer structure in Figure 6b. It can be seen that even if $\mathrm{Ag}$ limits the $\mathrm{Cu}$ diffusion into $\mathrm{MoO}_{3}$, without $\mathrm{Ag}$, the profile $\mathrm{Cu} / \mathrm{Mo}$ is flat, and there is a significant diffusion of $\mathrm{Cu}$ into Mo, with 40 at.\% of $\mathrm{Cu}$ present at the interfacing electrode/organic material. Nevertheless, in comparison with Figure 6b, at the center of the structure, when the thin layer of Ag is present, the atomic concentration of $\mathrm{Cu}$ is higher, while, on the other hand, it is lower in the $\mathrm{MoO}_{3}$ layer. This shows the effectiveness of this thin Ag layer in limiting the diffusion of $\mathrm{Cu}$. However, the presence of a relatively high concentration of $\mathrm{Cu}$ at the interface has a negative effect on the OPV performances. We have already shown that if an ultra-thin layer of $0.6 \mathrm{~nm}$ of $\mathrm{Cu}$ is an efficient anode buffer, this positive effect is destroyed when $\mathrm{Cu}$ is present in a thicker layer [33], which is the case at hand. The diffusion of $\mathrm{Cu}$ induces a decrease of the shunt resistance, resulting in poor rectifying properties. Moreover, the $\mathrm{Cu}$ diffusion results in an increase of the sheet resistance of the electrode. All that results in a decrease in the values of Voc, Jsc, FF, and efficiency. As in the case of $\mathrm{MoO}_{3} / \mathrm{Ag} / \mathrm{MoO}_{3}$, the performances are smaller when the OPV is illuminated from the top anode side, for the same reasons.

The partial diffusion of $\mathrm{Cu}$ into $\mathrm{MoO}_{3}$ in the $\mathrm{MoO}_{3} / \mathrm{Ag} / \mathrm{Cu}: \mathrm{Ag} / \mathrm{ZnS}$ structures justifies the fact that to obtain acceptable sheet resistance it is necessary to use thicker $(17 \mathrm{~nm})$ metal films in the case of these TCE, than in the case of $\mathrm{MoO}_{3} / \mathrm{Ag} / \mathrm{MoO}_{3}$.

Nevertheless, it must be underlined that, as regards results obtained with the $\mathrm{MoO}_{3} /$ $\mathrm{Ag} / \mathrm{MoO}_{3}$ anodes, the results obtained are at the level of results already published [34-37], but using here the simple PHJ-OPV configuration and based on well-known and inexpensive molecules. 


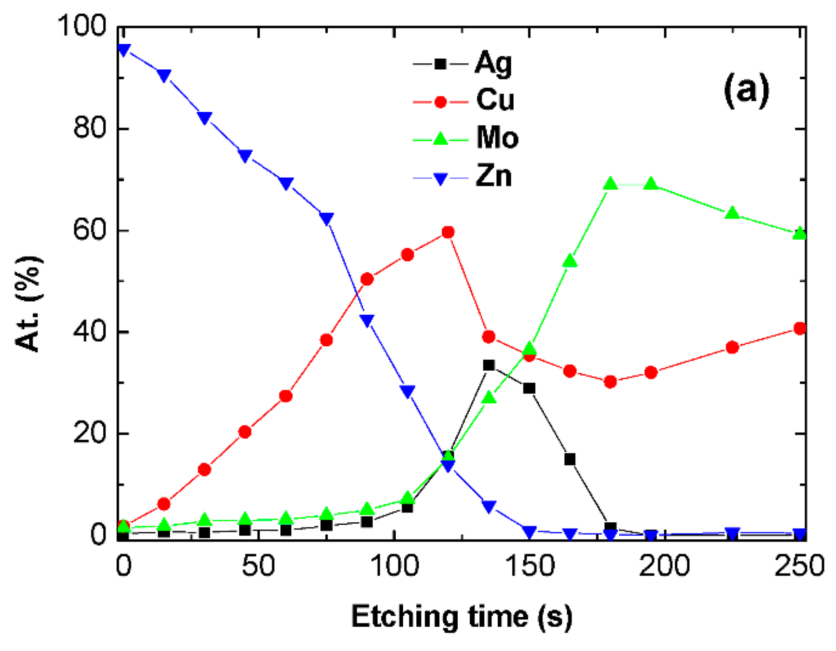

\begin{tabular}{|c|c|c|c|c|}
\hline ZnS & $\mathrm{Cu}: \mathrm{Ag}$ & $\mathbf{A g}$ & $\mathrm{MoO}_{3}$ & Glass \\
\hline
\end{tabular}

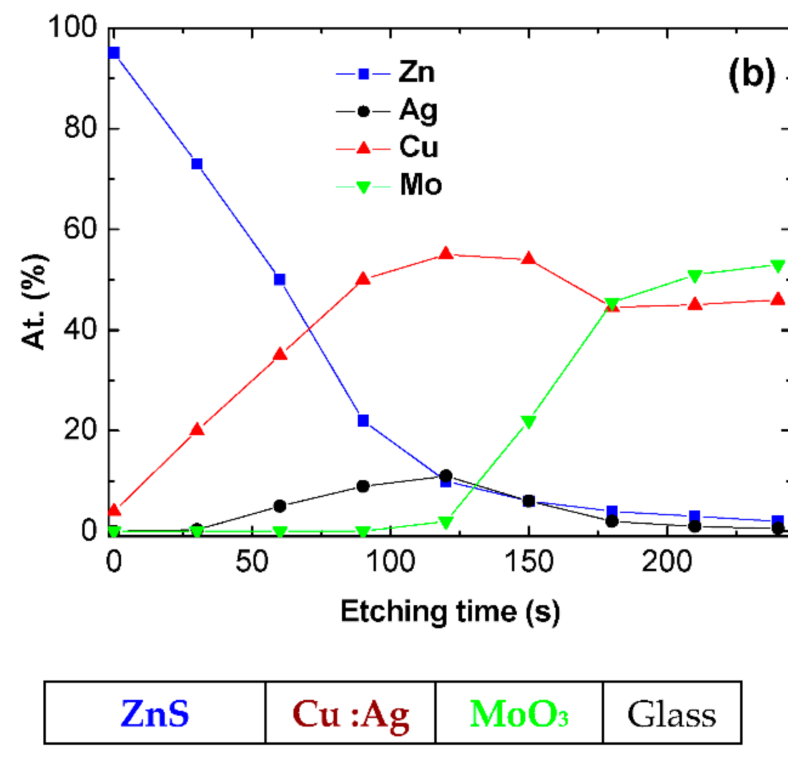

Figure 6. XPS profile of the electrodes $\mathrm{MoO}_{3} / \mathrm{Ag} / \mathrm{Cu}: \mathrm{Ag} / \mathrm{ZnS}(\mathbf{a})$ and $\mathrm{MoO}_{3} / \mathrm{Cu}: \mathrm{Ag} / \mathrm{ZnS}(\mathbf{b})$.

\section{Conclusions}

It can be said that, up to now, if DMD structures using $\mathrm{Ag}$ as metal and $\mathrm{MoO}_{3}$ as dielectric have been demonstrated to be highly efficient transparent electrode on top of OPVs, the results obtained with $\mathrm{MoO}_{3} / \mathrm{Ag} / \mathrm{Cu}: \mathrm{Ag} / \mathrm{ZnS}$ electrodes are not as convincing. Such a disappointing result is attributed to the fact that copper tends to diffuse in $\mathrm{MoO}_{3}$, even if the use of $\mathrm{Cu}: \mathrm{Ag}$ alloy permits limiting the $\mathrm{Cu}$ diffusion. That said, the results obtained with $\mathrm{MoO}_{3} / \mathrm{Ag} / \mathrm{MoO}_{3}$ top electrode are far most promising. An optimized $\mathrm{MoO}_{3} / \mathrm{Ag} / \mathrm{MoO}_{3}$ top electrode allows achieving semi-transparent OPVs with quite high transparency. Of course, this transparency penalizes the short circuit current and, therefore, the OPV efficiency; nevertheless, the performances of these OPVs put them among the most transparent OPVs for a yield of the same order of magnitude as those made with cells based on BHJ. In fact, since, in order to obtain semi-transparent OPVs, it is necessary to limit the thickness of the organic materials, the present work shows that the benefit of using $\mathrm{BHJ}$, which is very efficient in classical OPV, is lost here. In the case of semi-transparent OPVs, 
planar heterojunction appears to be a promising solution, paving the way toward building integrated photovoltaics (BIPVs) for their ease of production and high reproducibility.

In the case of $\mathrm{MoO}_{3} / \mathrm{Ag} / \mathrm{Cu}: \mathrm{Ag} / \mathrm{ZnS}$ electrodes, the performances of the DMD are diminished due to partial $\mathrm{Cu}$ diffusion into the dielectrics, mainly into $\mathrm{MoO}_{3}$. In order to improve the power conversion of OPV using a top electrode containing $\mathrm{Cu}$, we are now probing new DMD configurations:

- $\quad$ Since $\mathrm{Cu}$ diffusion in $\mathrm{ZnS}$ is far smaller than in $\mathrm{MoO}_{3}$, we are going to probe $\mathrm{MoO}_{3} /$

$\mathrm{ZnS} / \mathrm{Ag} / \mathrm{Cu}: \mathrm{Ag} / \mathrm{ZnS}$ structures. The bilayer of dielectric $\mathrm{MoO}_{3} / \mathrm{ZnS}$ has a dual goal:

- $\quad \mathrm{MoO}_{3}$ allows an efficient collection of holes;

- $\quad$ ZnS minimizes the diffusion of $\mathrm{Cu}$.

This should improve the efficiency of the cells.

Another possibility is to use another $\mathrm{Cu}$ alloy; we aim to replace $\mathrm{Cu}$ :Ag with other alloys such as $\mathrm{Cu}: \mathrm{Cr}$, as $\mathrm{Cr}$ is well-known as a diffusion barrier.

Supplementary Materials: The following are available online at https:/ / www.mdpi.com/2079-4991/11 /2/393/s1, S1: Preparation of the substrates and deposition conditions; S2: Characterization techniques.

Author Contributions: All authors contributed equally to this publication. All authors have read and agreed to the published version of the manuscript.

Funding: The authors acknowledge funding from the European Community ERANETMED_ENERG11-196.

Data Availability Statement: Data are available.

Conflicts of Interest: The authors declare no conflict of interest. The funders had no role in the design of the study; in the collection, analyses, or interpretation of data; in the writing of the manuscript, or in the decision to publish the results.

\section{References}

1. Almora, O.; Baran, D.; Bazan, G.C.; Berger, C.; Cabrera, C.I.; Catchpole, K.R.; Erten-Ela, S.; Guo, F.; Hauch, J.; Ho-Baillie, A.W.Y.; et al. Device Performance of Emerging Photovoltaic Materials (Version 1). Adv. Energy Mater. 2020, 2002774. [CrossRef]

2. Cui, Y.; Yao, H.; Hong, L.; Zhang, T.; Tang, Y.; Lin, B.; Xian, K.; Gao, B.; An, C.; Bi, P.; et al. Organic photovoltaic cell with 17\% efficiency and superior processability. Natl. Sci. Rev. 2020, 7, 1239-1246. [CrossRef]

3. Yao, H.; Wang, J.; Xu, Y.; Zhang, S.; Hou, J. Recent Progress in Chlorinated Organic Photovoltaic Materials. Acc. Chem. Res. 2020, 53, 822-832. [CrossRef]

4. Xue, R.; Zhang, J.; Li, Y.; Li, Y. Organic Solar Cell Materials toward Commercialization. Small 2018, 14, 1801793. [CrossRef]

5. Song, Y.; Zhang, K.; Dong, S.; Xia, R.; Huang, F.; Cao, Y. Semitransparent Organic Solar Cells Enabled by a Sequentially Deposited Bilayer Structure. ACS Appl. Mater. Interfaces 2020, 12, 18473-18481. [CrossRef]

6. Li, Y.; Guo, X.; Peng, Z.; Qu, B.; Yan, H.; Ade, H.; Zhang, M.; Forrest, S.R. Color-neutral, semitransparent organic photovoltaics for power window applications. Proc. Natl. Acad. Sci. USA 2020, 117, 21147-21154. [CrossRef]

7. Rwenyagila, E.R. A Review of Organic Photovoltaic Energy Source and Its Technological Designs. Int. J. Photoenergy 2017, 1656512. [CrossRef]

8. Gaspar, H.; Figueira, F.; Pereira, L.; Mendes, A.; Viana, J.C.; Bernardo, G. Recent Developments in the Optimization of the Bulk Heterojunction Morphology of Polymer: Fullerene Solar Cells. Materials 2018, 11, 2560. [CrossRef]

9. Han, Y.W.; Jeon, S.J.; Lee, H.S.; Park, H.; Kim, K.S.; Lee, H.-W.; Moon, D.K. Evaporation-Free Nonfullerene Flexible Organic Solar Cell Modules Manufactured by An All-Solution Process. Adv. Energy Mater. 2019, 1902065. [CrossRef]

10. Jeon, S.J.; Han, Y.W.; Moon, D.K. 13.9\%-Efficiency and Eco-Friendly Nonfullerene Polymer Solar Cells Obtained by Balancing Molecular Weight and Solubility in Chlorinated Thiophene-Based Polymer Backbones. Small 2019, 1902598. [CrossRef]

11. Jeon, S.J.; Han, Y.W.; Kim, Y.H.; Moon, D.K. Case Study on the Correlation between Crystal Packing and Miscibility of Chlorinated Thiophene-Based Donor Polymers for Nonfullerene Organic Solar Cells with Long Shelf Life. Sol. RRL 2020, 4, 2000074. [CrossRef]

12. Bernède, J.C. Organic photovoltaic cells: History, principle and techniques. J. Chil. Chem. Soc. 2008, 53, 1549-1564. [CrossRef]

13. Chen, K.-W.; Huang, C.-W.; Lin, S.-Y.; Liu, Y.-H.; Chatterjee, T.; Hung, W.-Y.; Liu, S.-W.; Wong, K.-T. Merocyanines for vacuumdeposited small-molecule organic solar cells. Org. Electr. 2015, 26, 319-326. [CrossRef]

14. Po, R.; Roncali, J. Beyond efficiency: Scalability of molecular donor materials for organic photovoltaics. Mater. Chem. C 2016, 4, 3677. [CrossRef] 
15. Badgujar, S.; Lee, G.-Y.; Park, T.; Song, C.E.; Park, S.; Oh, S.; Shin, W.S.; Moon, S.-J.; Lee, J.-C.; Lee, S.K. High-Performance Small Molecule via Tailoring Intermolecular Interactions and its Application in Large-Area Organic Photovoltaic Modules. Adv. Energy Mater. 2016, 1600228. [CrossRef]

16. Galindo, S.; Ahmadpour, M.; Gerling, L.G.; Marsal, A.; Voz, C.; Alcubilla, R.; Puigdollers, J. Influence of the density of states on the open-circuit voltage in small-molecule solar cells. Org. Electr. 2014, 15, 2553-2560. [CrossRef]

17. Cnops, K.; Rand, B.P.; Cheyns, D.; Verreet, B.; Empl, M.A.; Heremans, P. 8.4\% efficient fullerene-free organic solar cells exploiting long-range exciton energy transfer. Nat. Commun. 2014, 5, 3406. [CrossRef]

18. Camic, B.T.; Jeong, H.I.; Aslan, M.H.; Kosemen, A.; Kim, S.; Choi, H.; Basarir, F.; Lee, B.R. Preparation of Transparent Conductive Electrode via Layer-By-Layer Deposition of Silver Nanowires and Its Application in Organic Photovoltaic Device. Nanomaterials 2020, 10, 46. [CrossRef]

19. Guillén, C.; Herrero, J. TCO/metal/TCO structures for energy and flexible electronics. Thins Solid Films 2011, 520, 1-17. [CrossRef]

20. Cattin, L.; Bernède, J.C.; Morsli, M. Toward indium-free optoelectronic devices: Dielectric/Metal/Dielectric alternative conductive transparent electrode in organic photovoltaic cells Phys. Status Solidi A 2013, 210, 1047-1061. [CrossRef]

21. Gong, Y.; Dong, Y.; Zhao, B.; Yu, R.; Hub, S.; Tan, Z. Diverse applications of $\mathrm{MoO}_{3}$ for high performance organic photovoltaics: Fundamentals, processes and optimization strategies. J. Mater. Chem. A 2020, 8, 978. [CrossRef]

22. Cattin, L.; Dahou, F.; Lare, Y.; Morsli, M.; Tricot, R.; Houari, S.; Mokrani, A.; Jondo, K.; Khelil, A.; Napo, K.; et al. MoO 3 surface passivation of the transparent anode in organic solar cells using ultrathin films. J. Appl. Phys. 2009, 105, 034507. [CrossRef]

23. Bernède, J.C.; Cattin, L. Dielectric/Metal/Dielectric flexible transparent electrodes, from smart window to semi-transparent solar cells. Asian J. Eng. Technol. 2019, 7, 176-195.

24. Pérez Lopéz, I.; Cattin, L.; Nguyen, D.-T.; Morsli, M.; Bernède, J.C. Dielectric/metal/dielectric structures using copper as metal and $\mathrm{MoO}_{3}$ as dielectric for use as transparent electrode. Thin Solid Films 2012, 520, 6419-6423. [CrossRef]

25. Cattin, L.; El Mahlali, A.; Cherif, M.A.; Touihri, S.; El Jouad, Z.; Mouchaal, Y.; Blanchard, P.; Louarn, G.; Essaidi, H.; Addou, M.; et al. New dielectric/metal/dielectric electrode for organic photovoltaic cells using Cu:Al alloy as metal. J. Alloys Compd. 2020, 819, 152974. [CrossRef]

26. Wang, K.; Liu, C.; Meng, T.; Yi, C.; Gong, X. Inverted organic photovoltaic cells. Chem. Soc. Rev. 2016, 45, 2937-2975. [CrossRef]

27. El Jouad, Z.; Morsli, M.; Louarn, G.; Cattin, L.; Addou, M.; Bernède, J.C. Improving the efficiency of subphthalocyanine based planar organic solar cells through the use of $\mathrm{MoO}_{3} / \mathrm{CuI}$ double anode buffer layer. Sol. Energy Mater. Sol. Cells 2015, 141, 429-435. [CrossRef]

28. Cattin, L.; Cherif, M.A.; El Jouad, Z.; Ftouhi, H.; El-Menyawy, E.M.; El Mahlali, A.; Touihri, S.; Arzel, L.; Addou, M.; Torchio, P.; et al. On the contribution of fullerene to the, current of planar heterojunction organic solar cells. J. Phys. D Appl. Phys. 2020, 53, 225501. [CrossRef]

29. Rand, B.P.; Lian, J.; Xue, J.; Holmes, R.J.; Thompson, M.E.; Forrest, S.R. Organic Double-Heterostructure Photovoltaic Cells Employing Thick Tris(acetylacetonato) ruthenium(III) Exciton-Blocking Layers. Adv. Mater. 2005, 17, 2714-2718. [CrossRef]

30. Song, Q.L.; Li, F.Y.; Yang, H.; Wu, H.R.; Wang, X.Z.; Zhou, W.; Zhao, J.M.; Ding, X.M.; Huang, C.H.; Hou, X.Y. Small-molecule organic solar cells with improved stability. Chem. Phys. Lett. 2005, 416, 42-46. [CrossRef]

31. Haacke, G. New figure of merit for transparent conductors. J. Appl. Phys. 1976, 47, 4086-4089. [CrossRef]

32. Bou, A.; Torchio, P.; Vedraine, S.; Barakel, D.; Lucas, B.; Bernède, J.C.; Thoulon, P.-Y.; Ricci, M. Numerical optimization of multilayer electrodes without indium for use in organic solar cells. Sol. Energy Mater. Sol. Cells 2014, 125, 310-317. [CrossRef]

33. Berredjem, Y.; Bernéde, J.C.; Ouro Djobo, S.; Cattin, L.; Morsli, M.; Boulmokh, A. On the improvement of the efficiency of organic photovoltaic cells by the presence of an ultra-thin metal layer at the interface organic/ITO. Eur. Phys. J. Appl. Phys. 2008, 44, 223-228. [CrossRef]

34. Winkler, T.; Schmidt, H.; Flügge, H.; Nikolayzik, F.; Baumann, I.; Schmale, S.; Weimann, T.; Hinze, P.; Johannes, H.-H.; Rabe, T.; et al. Efficient large area semitransparent organic solar cells based on highly transparent and conductive ZTO/Ag/ZTO multilayer top electrodes. Org. Electr. 2011, 12, 1612-1618. [CrossRef]

35. Lim, S.J.; Kim, D.U.; Song, J.-H.; Yu, J.-W. Enhanced performance of semi-transparent OPV with nanoparticle reflectors. Org. Electr. 2018, 59, 314-318. [CrossRef]

36. Tao, C.; Xie, G.; Liu, C.; Zhang, X.; Dong, W.; Meng, F.; Kong, X.; Shen, L.; Ruan, S.; Chen, W. Semitransparent inverted polymer solar cells with $\mathrm{MoO}_{3} / \mathrm{Ag} / \mathrm{MoO}_{3}$ as transparent electrode. Appl. Phys. Lett. 2009, 95, 053303. [CrossRef]

37. Li, F.; Ruan, S.; Xu, Y.; Meng, F.; Wang, J.; Chen, W.; Shen, L. Semitransparent inverted polymer solar cells using $\mathrm{MoO}_{3} / \mathrm{Ag} / \mathrm{WO}_{3}$ as highly transparent anodes. Sol. Energy Mater. Sol. Cells 2011, 95, 877-880. [CrossRef] 